\title{
Możliwość dochodzenia przez byłych właścicieli lub ich następców prawnych zwrotu nieruchomości, które zostały przejęte na własność Skarbu Państwa na podstawie dekretu z 1949 r. $^{1}$
}

\begin{abstract}
The possibility for former owners or their successors to seek reimbursement regarding real estates which have been taken over by the State Treasury pursuant to the Decree of 1949: In the light of applicable regulations former owners of real estates or their legal successors have the right to demand the return of real estates taken over by the State Treasury pursuant to provisions of the Decree of 27 July 1949 or have the right to claim compensation only if, in the course of supervisory control, the voivode states that the decision of the Presidium of the Poviat National Council, on the basis of which the loss of property occurred, is invalid or considers, that the decision was made illegally. In the current legal situation former owners or their legal successors have no legal instruments to enforce any reprivatisation claims they may have: the return of real estate or compensation.
\end{abstract}

Keywords: real estate, compensation, reprivatisation, property

Słowa kluczowe: nieruchomość, odszkodowanie, reprywatyzacja, własność

\section{Przedmiot opinii}

Przedmiotem niniejszej opinii jest analiza obowiązującego stanu prawnego w celu ustalenia, czy byli właściciele nieruchomości lub ich następcy prawni

1 Opinia prawna dotyczaca możliwości dochodzenia przez bytych właścicieli lub ich następców prawnych zwrotu nieruchomości, które zostaly przejęte na własność Skarbu Państwa na podstawie dekretu $z$ dnia 27 lipca 1949 r. o przejęciu na własność Państwa niepozostających w faktycznym władaniu właścicieli nieruchomości ziemskich, położonych w niektórych powiatach województwa białostockiego, lubelskiego, rzeszowskiego $i$ krakowskiego lub roszczenia odszkodowawczego sporządzona 20 marca 2019 r. na zlecenie posła Klubu Parlamentarnego Prawo i Sprawiedliwość; BAS-WAP 385/19. 
mają możliwość wyegzekwowania ewentualnie przysługujących im roszczeń reprywatyzacyjnych (zwrotu mienia lub odszkodowania) w związku z przejęciem nieruchomości na własność Skarbu Państwa na podstawie dekretu z 27 lipca 1949 r. o przejęciu na własność Państwa nie pozostających w faktycznym władaniu właścicieli nieruchomości ziemskich, położonych w niektórych powiatach województwa białostockiego, lubelskiego, rzeszowskiego i krakowskiego.

W opinii zostały wykorzystane następujące akty prawne:

- dekret z 27 lipca 1949 r. o przejęciu na własność Państwa nie pozostających w faktycznym władaniu właścicieli nieruchomości ziemskich, położonych w niektórych powiatach województwa białostockiego, lubelskiego, rzeszowskiego i krakowskiego, Dz.U. 1949, nr 46, poz. 339, ze zm.; dalej: dekret lub dekret z 27 lipca 1949 r.,

- ustawa z 14 czerwca 1960 r. - Kodeks postępowania administracyjnego, t.j. Dz.U. 2018, poz. 2096, ze zm.; dalej: k.p.a.,

- ustawa z 17 czerwca 2004 r. o zmianie ustawy - Kodeks cywilny oraz niektórych innych ustaw, Dz.U. nr 162, poz. 1692; dalej: ustawa nowelizująca.

Należy zaznaczyć, że niniejsza opinia ma charakter abstrakcyjny, nie odnosi się do ściśle określonego stanu faktycznego ani nie może być postrzegana jako stanowisko w indywidualnej sprawie.

\section{Uwagi wstępne}

Artykuł 1 dekretu z 27 lipca 1949 r. stanowił, że: (1) Moga być przejmowane na własność Państwa $w$ całości lub $w$ części nieruchomości ziemskie położone $w$ województwach: białostockim, lubelskim; rzeszowskim i krakowskim w obrębie pasa granicznego, przewidzianego w rozporzadzeniu Prezydenta Rzeczypospolitej z dnia 23 grudnia 1927 r. o granicach Państwa (Dz.U.R.P. z 1937 r. Nr 11, poz. 83), oraz w powiatach: biłgorajskim, krasnystawskim i lubelskim województwa lubelskiego oraz brzozowskim i przeworskim województwa rzeszowskiego, jeżeli nie pozostaja w faktycznym władaniu właścicieli. (2) Przepis ust. 1 stosuje się również do nieruchomości położonych na obszarze $w$ tym ustępie określonym, a pozostajacych w użytkowaniu, dzierżawie lub zarządzie osób trzecich, jeżeli właściciel nie zamieszkuje na miejscu.

O przejęciu nieruchomości ziemskich na własność państwa orzekała powiatowa władza administracji ogólnej (art. 3 ust. 1 dekretu). Z powyższego przepisu wynika, że decyzja powiatowej władzy administracji ogólnej - Prezydium Powiatowej Rady Narodowej - miała charakter konstytutywny, gdyż przepisy tego dekretu nie przewidywały przejmowania z mocy prawa nieruchomości, które nie były we władaniu właścicieli, lecz dopuszczały możliwość ich przejęcia na własność państwa. 
Orzeczenie o przejęciu nieruchomości ziemskiej na własność państwa stanowiło podstawę do ujawnienia w księgach wieczystych i w zbiorach dokumentów na wniosek powiatowej władzy administracji ogólnej przejścia własności na rzecz Skarbu Państwa (art. 4 ust. 1 dekretu).

$\mathrm{Na}$ podstawie art. 5 ust. 1 dekretu byłym właścicielom i współwłaścicielom nieruchomości, przejętych na własność państwa z mocy dekretu, przysługiwało wyłącznie prawo do otrzymania na własność gospodarstwa (działki) z innych gruntów bądź też prawo do nabycia mienia nierolniczego na zasadach określonych w tym przepisie. Prawo do zgłoszenia wniosku o przydział mienia, o którym mowa w art. 5 ust. 1 dekretu, wygasało po upływie dwóch lat od daty wydania ostatecznego orzeczenia o przejęciu nieruchomości lub uprawomocnieniu się orzeczenia I instancji (art. 5 ust. 2 dekretu).

\section{Uwagi ogólne dotyczące możliwości dochodzenia przez byłych właścicieli lub ich następców prawnych zwrotu nieruchomości przejętej na podstawie dekretu z 27 lipca 1949 r. lub odszkodowania}

W obowiązującym stanie prawnym podstawę roszczeń o zwrot przejętego mienia lub roszczeń odszkodowawczych byłych właścicieli oraz ich następców prawnych (spadkobierców) może stanowić bezprawność decyzji nacjonalizacyjnych. W świetle przepisów Kodeksu postępowania administracyjnego można stwierdzić nieważność decyzji administracyjnej (art. $156 \$ 1$ k.p.a.), na podstawie której doszło do utraty mienia, bądź uznać taką decyzję za niezgodną z prawem (art. $158 \$ 2$ k.p.a.). W sytuacji, w której zostanie wydana decyzja stwierdzająca nieważność decyzji o przejęciu mienia, należy uznać, że państwo nigdy nie stało się właścicielem przedmiotowego mienia, a jedynie objęło je w bezumowne faktyczne władanie, a zatem w takim wypadku właścicielowi oraz jego następcom prawnym przysługuje roszczenie o wydanie mienia, a jeśli niemożliwe jest odzyskanie mienia w naturze, podmiotom uprawnionym przysługuje odszkodowanie.

Podstawą żądania odszkodowania jest art. $160 \$ 1$ k.p.a. w związku z art. 5 ustawy nowelizującej.

\section{Uwagi dotyczące możliwości dochodzenia przez byłych właścicieli lub ich następców prawnych odszkodowania na podstawie art. 160 k.p.a. w związku $z$ art. 5 ustawy nowelizującej}

Sąd Najwyższy w uchwale z 1 marca 2011 r., sygn. akt III CZP 112/10, podjętej przez skład pełnej Izby Cywilnej - w celu rozstrzygnięcia problemu intertempo- 
ralnego w zakresie stosowania art. 160 k.p.a. - odwołał się do art. 5 ustawy nowelizującej. Zgodnie z tym przepisem: do zdarzeń $i$ stanów prawnych powstałych przed dniem wejścia w życie niniejszej ustawy stosuje się [...] art. 160 k.p.a. [...] $w$ brzmieniu obowiązującym do dnia wejścia $w$ życie niniejszej ustawy. Przytoczony przepis ma charakter normy prawa międzyczasowego materialnego; rozgranicza on zastosowanie art. 160 k.p.a. uchylonego z dniem 1 września 2004 r. i ustanowionego z mocą od tego dnia art. $417^{1} \$ 2$ Kodeksu cywilnego. W świetle art. 5 ustawy nowelizującej do roszczeń o naprawienie szkody wyrządzonej ostateczną decyzją administracyjną wydaną przed dniem 1 września 2004 r., której nieważność lub wydanie $\mathrm{z}$ naruszeniem art. $156 \$ 1$ k.p.a. stwierdzono po tym dniu, ma zastosowanie art. $160 \$ 1, \$ 2, \S 3$ k.p.a. Sąd Najwyższy podkreślił, że w sprawach o naprawienie szkody wyrządzonej wydaniem decyzji administracyjnej łącznikiem międzyczasowym jest wyłącznie pojęcie „zdarzenia”. Pojęcia „zdarzenia” nie można interpretować zgodnie z koncepcją „zdarzenia złożonego”. Przemawia za tym przede wszystkim normatywna identyfikacja źródła wyrządzenia szkody w przepisach o czynach niedozwolonych. Według art. $417^{1} \$ \mathrm{Ko}-$ deksu cywilnego, podobnie jak i według innych przepisów wprowadzonych do Kodeksu cywilnego ustawą nowelizującą, czynem niedozwolonym jest samo: $w y$ danie niezgodnego z prawem prawomocnego orzeczenia lub niezgodnej z prawem ostatecznej decyzji. Także art. 160 k.p.a., według dominującego poglądu, ustanawiał samodzielną podstawę odpowiedzialności deliktowej za szkody związane z wydaniem naruszającej prawo ostatecznej decyzji. Decyzja nadzorcza jakkolwiek ma charakter prejudykatu przesądzającego o jednej z przesłanek omawianej odpowiedzialności deliktowej - bezprawności działania organu przy wydaniu decyzji - nie może być uznana za „zdarzenie” w rozumieniu art. 5 przepisu przejściowego ani element tego „zdarzenia”. Decyzja nadzorcza, zarówno stwierdzająca nieważność wadliwej decyzji, jak i wydanie jej z naruszeniem prawa, ma bowiem moc wsteczną i rozstrzyga tylko o tym, że będąca jej przedmiotem decyzja była aktem bezprawnym, a więc stanowiła czyn niedozwolony, rodzący obowiązek odszkodowawczy już w chwili jej wydania. Sama decyzja nadzorcza nie jest jednak czynem niedozwolonym wyrządzającym szkodę, lecz działaniem zgodnym z prawem, otwierającym drogę do dochodzenia odszkodowania.

W kwestii zasadności stosowania $\$ 6$ art. 160 k.p.a. Sąd Najwyższy w uchwale z 31 marca 2011 r., sygn. akt III CZP 112/10, wyraził następujące stanowisko: Wobec możliwości domagania się na podstawie art. 160 k.p.a., w związu z jego moca wsteczna, odszkodowania także za szkody wyrzadzone decyzjami wydanymi przed kilkudziesięciu laty - jeżeli tylko ich nieważność lub wydanie z naruszeniem prawa stwierdzono po dniu 31 sierpnia 1980 r. (por. art. $156 \$ 2$ k.p.a.) - jedynym odpowiednim rozwiązaniem było przyjęcie, że przedawnienie roszczenia o odszkodowanie rozpoczyna bieg od dnia, w którym stała się ostateczna decyzja stwierdzajaca nieważność decyzji wydanej z naruszeniem przepisu art. $156 \$ 1$ albo decyzja, w której organ stwierdził, w myśl art. $158 \$ 2$, że zaskarżona decyzja została wydana z naruszeniem 
przepisu art. $156 \$ 1$. Zastosowanie innego rozwiązania, spośród spotykanych sposobów określenia początku biegu przedawnienia roszczenia, czyniłoby tę odpowiedzialność iluzoryczna lub w najlepszym razie sprzyjało wikłaniu się stron w spory na tle przedawnienia dochodzonego roszczenia. $\mathrm{Z}$ treści przytoczonego uzasadnienia przytoczonej uchwały Sądu Najwyższego jednoznacznie wynika, że $\$ 6$ art. 160 k.p.a., dotyczący przedawnienia roszczenia odszkodowawczego, ma zastosowanie wówczas, gdy roszczenie jest dochodzone na podstawie art. $160 \$ 1$, $\$ 2$, $\$ 3$ k.p.a.

Reasumując, należy stwierdzić, że w świetle cytowanej uchwały Sądu Najwyższego uchylony przepis art. $160 \$ 1, \S 2, \S 3$ i $\$ 6$ k.p.a. ma zastosowanie do roszczeń o naprawienie szkody wyrządzonej ostateczną decyzją administracyjną wydaną przed dniem 1 września 2004 r., której nieważność lub wydanie z naruszeniem art. $156 \$ 1$ k.p.a. stwierdzono po tym dniu, z tym że zakres odszkodowania może być różny w zależności od tego, czy decyzja ta została wydana przed wejściem w życie Konstytucji z 1997 r., czy po jej wejściu w życie. Jeżeli ostateczna decyzja administracyjna została wydana przed wejściem w życie Konstytucji - 17 października 1997 r., odszkodowanie przysługujące na podstawie art. $160 \$ 1$ k.p.a. nie obejmuje korzyści utraconych wskutek jej wydania, choćby utrata nastąpiła po wejściu w życie Konstytucji; jeżeli zaś decyzja została wydana po tej dacie a przed 1 września 2004 r., podstawę odszkodowania nadal będzie stanowił art. $160 \$ 1$ k.p.a., z tym zastrzeżeniem że nie może on być stosowany w zakresie, w jakim ogranicza skalę odszkodowania do rzeczywistej szkody.

\section{Uwagi dotyczące organu właściwego do stwierdzenia nieważności decyzji - orzeczenia o przejęciu nieruchomości ziemskich na własność państwa}

W orzecznictwie pojawiły się wątpliwości co do kompetencji organu właściwego do prowadzenia postępowania nadzorczego odnośnie do decyzji wydanych w przeszłości przez prezydium powiatowej rady narodowej, czyli organ, który w wyniku przeprowadzonych zmian strukturalnych został zniesiony.

Pierwotnie wykształciła się praktyka orzecznicza sądów administracyjnych, która wskazywała na samorządowe kolegia odwoławcze jako organy właściwe do rozpatrywania wniosków o stwierdzenia nieważności orzeczeń prezydiów powiatowych rad narodowych dotyczących przejęcia na własność Skarbu Państwa nieruchomości ziemskich ${ }^{2}$. Ta linia orzecznicza została skrytykowana w postanowieniu Naczelnego Sądu Administracyjnego z 24 lutego 2011 r., sygn. akt I OW 181/10, który podkreślił, że: [s]koro $w$ prawie materialnym nie istnieje kategoria spraw do-

2 Zob. wyroki Wojewódzkiego Sądu Administracyjnego w Warszawie z: 10 maja 2007 r., sygn. akt IV SA/WA 351/07, Legalis nr 110907; 18 października 2005 r., sygn. akt IV SA/Wa 1307/05, Legalis nr 1131903. 
tyczacych przejmowania na własność Państwa nieruchomości na podstawie dekretu $z 1949$ r., a ustawodawca po tej dacie nie wskazał wprost organów właściwych do weryfikowania orzeczeń Prezydiów Powiatowych Rad Narodowych dotyczacych przejęcia na własność Skarbu Państwa nieruchomości ziemskich wydanych w trybie dekretu o przejęciu na własność Państwa niepozostających w faktycznym władaniu właścicieli nieruchomości ziemskich położonych w niektórych powiatach województwa białostockiego, lubelskiego, rzeszowskiego i krakowskiego, to nie można domniemywać ani kompetencji gminy ani właściwości samorządowych kolegiów odwoławczych w tych sprawach. Błędny jest zatem poglad [...], że organem wyższego stopnia właściwym do prowadzenia postępowań weryfikacyjnych, w tym o stwierdzenie nieważności decyzji, w przedmiotowych sprawach jest, na podstawie art. 17 k.p.a., samorzadowe kolegium odwoławcze, jako organ wyższego stopnia w stosunku do organów jednostek samorządu terytorialnego. Tym bardziej, że przejmowanie nieruchomości na własność Państwa nie było i nie jest zadaniem własnym gminy (samorząu terytorialnego) - właściwość organów gminy mogła i może obejmować takie sprawy tylko, jako zadania zlecone z zakresu administracji rzadowej. Z powyższych względów organami właściwymi w postępowaniach weryfikacyjnych $w$ tych sprawach sq organy administracji rzadowej. Przypomnieć należy, że sprawy zakończone wydaniem przez Prezydia Powiatowych Rad Narodowych orzeczeń w zakresie przejęcia na własność Skarbu Państwa nieruchomości ziemskich wydanych $w$ trybie dekretu $z 1949$ r., wtedy gdy istniały, należały do kategorii spraw z zakresu administracji rządowej. O przejęciu nieruchomości ziemskich na własność Państwa orzekała bowiem powiatowa władza administracji ogólnej (art. 3 ust. 1 dekretu), zaś orzeczenie o przejęciu nieruchomości ziemskiej na własność Państwa stanowiło podstawe do ujawnienia $w$ księgach wieczystych $i w$ zbiorach dokumentów na wniosek powiatowej władzy administracji ogólnej przejścia własności na rzecz Skarbu Państwa (art. 4 ust. 1 dekretu).[...] Wedtug art. 3 ust. 1 pkt 5 ustawy [z 23 stycznia 2009 r. o wojewodzie i administracji rządowej w województwie (Dz.U. nr 31, poz. 206), która weszła w życie w dniu 1 kwietnia 2009 r. - dopisek J.W.-N.] do właściwości wojewody, jako organu administracji rządowej $w$ województwie należa wszystkie sprawy z zakresu administracji rządowej w województwie, niezastrzeżone w odrębnych ustawach na rzecz innych organów tej administracji [...] Jeżeli zatem $z$ odrębnych ustaw nie wynika, który z organów administracji rządowej jest właściwy $w$ określonej sprawie z zakresu administracji rządowej, to organem właściwym $w$ takiej sprawie tak̇̇e, jako organ wyższego stopnia, jest wojewoda ${ }^{3}$.

Reasumując, należy stwierdzić, że organem właściwym do weryfikowania orzeczeń prezydiów powiatowych rad narodowych - dotyczących przejęcia na własność Skarbu Państwa nieruchomości ziemskich wydanych w trybie dekretu z 27 lipca 1949 r. - jest wojewoda.

3 Postanowienie Naczelnego Sądu Administracyjnego z 24 lutego 2011 r., sygn. akt I OW 181/10, Legalis nr 615842. 


\section{Podsumowanie}

W świetle obowiązujących przepisów byli właściciele nieruchomości lub ich następcy prawni mają prawo żądać zwrotu nieruchomości przejętych na własność Skarbu Państwa na podstawie przepisów dekretu z 27 lipca 1949 r. lub mają prawo wystąpić z roszczeniem odszkodowawczym tylko wówczas, gdy w trybie kontroli nadzorczej wojewoda stwierdzi, że decyzja prezydium powiatowego rady narodowej, na podstawie której doszło do utraty mienia, jest nieważna (art. 156 $\$ 1$ k.p.a.) bądź uzna, że decyzja została wydana niezgodnie z prawem (art. 158 $\$ 2$ k.p.a.).

Mając na względzie powyższe zasady dotyczące realizacji roszczeń reprywatyzacyjnych, należy uznać, że w obecnym stanie prawnym nie ma instrumentów prawnych, które - w przypadku wydania orzeczenia prezydium powiatowej rady narodowej zgodnie z obowiązującymi wówczas przepisami - umożliwiałyby byłym właścicielom lub ich następcom prawnym wyegzekwowanie ewentualnie przysługujących im roszczeń reprywatyzacyjnych: zwrotu nieruchomości lub odszkodowania.

Można wspomnieć, że występujący problem w praktyce dostał dostrzeżony Ministerstwo Sprawiedliwości przygotowano projekt ustawy z 20 października 2017 r. o zrekompensowaniu niektórych krzywd wyrządzonych osobom fizycznym wskutek przejęcia nieruchomości lub zabytków ruchomych przez władze komunistyczne po 1944 r., w którym zostały określone zasady przyznawania i wykonywania prawa do rekompensaty na rzecz osób fizycznych, których nieruchomości lub zabytki ruchome zostały przejęte przez władze komunistyczne po 1944 r. na rzecz państwa lub na rzecz innych osób prawnych prawa publicznego, w tym jednostek samorządu terytorialnego (nieruchomości przejęte). Rada Legislacyjna przy Prezesie Rady Ministrów przygotowała krytyczną opinię o tym projekcie ustawy ${ }^{4}$.

4 Zob. opinia z 12 stycznia 2018 r. o projekcie ustawy o zrekompensowaniu niektórych krzywd wyrządzonych osobom fizycznym wskutek przejęcia nieruchomości lub zabytków ruchomych przez władze komunistyczne po 1944 r., https://radalegislacyjna. gov.pl/dokumenty/opinia-z-12-stycznia-2018-r-o-projekcie-ustawy-o-zrekompensowaniu-niektorych-krzywd [dostęp 19 marca 2019 r.]. 